\section{Den arkaisk moderne}

\section{Herbert Blomstedt ${ }^{1}$ om Carl Nielsen}

$\mathrm{N}$ ielsens symfonier er fantastisk musik. Han er en ægte symfoniker, ligesom Sibelius - de to er født samme år, 1865, men de er helt forskellige. Det hænger også sammen med de lande de kommer fra. Carl Nielsen er praktisk talt født i det samme land som Brahms - Brahms i Hamburg, Nielsen på den danske ø Fyn, i det samme flade, men rige kulturlandskab, nær ved havet. Nielsens første symfoni har ikke så lidt Brahms ved sig, uden at være en Brahms-kopi. Hos Nielsen mærker man straks at han er fast forankret i den tyske tradition. For at tale med hans tid: Der er et stykke af en antiromantiker i Nielsen, uden at han i sit hjerte ligefrem var antiromantiker. Nej, hans musik er meget udtryksfuld, er bekendelse. Men han var nået til den overbevisning at man ikke kunne videreudvikle Wagners tonesprog. Wagner havde drevet den kromatiske harmonik til det yderste, måske gik det et stykke endnu med Max Reger, men så var det uigenkaldeligt slut. I de nordiske lande og også i Tyskland orienterede mange komponister i Nielsens generation sig igen mod de gamle mestre: Hindemith for eksempel frem for alt mod barokken, Nielsen mere mod renæssancen.

Man greb tilbage til den lineære kompositionsmåde, og netop ikke som skinpolyfoni som hos Wagner eller Strauss hvor man kombinerer melodier som supplerer hinanden vidunderligt, men som alle bevæ- ger sig i det samme harmoniske område og derfor ikke rigtig kontrasterer. Det handlede tværtimod om rigtig polyfoni, hvori linierne nu og da støder meget dissonant sammen, og det førte også en ny anvendelse af tonearterne med sig. Nielsen har et meget udvidet toneartsbegreb. Tonearten bliver selv til en del af formen. Han udskyder tonearter: Når han i første sats af den tredje symfoni begynder i d-mol og vil slutte i dominanten A-dur, så gemmer han denne A-dur for at opnå en endnu større virkning, passerer til gengæld gennem mange andre tonearter på en ganske logisk måde, efter sin egen logik. Tonearterne bliver meget friere, men også meget mere bevidst anvendt. Nielsens melodier er diatoniske, altså ikke kromatiske, og de făr derved noget arkaisk over sig, man fristes nu og da næsten til at sige: noget middelalderligt, vikingeagtigt. Kvarten og endnu mere kvinten spiller en kolossal rolle. Det er en fuldstændig tonal musik, en harmonisk, "smukt" klingende musik, og dog absolut original og personlig. Derfor også "moderne".

Nielsens orkestersprog er meget stærkt, af og til endog noget djærvt, meget raffineret, men det har intet med fintfølende delikatesse som hos Ravel og Strauss at gøre. Hovedspændingen ligger hos Nielsen altid i musikken selv, i intervalspændingerne og $\mathrm{i}$ spændingerne mellem orkestrets klangblokke. Hver eneste node er kolossalt vigtig. Hvis man hos Richard Strauss for eksempel fjerner klarinetterne i et stort orkestertutti, forbliver musikken dog den samme. Hvis man fjerner noget hos Nielsen, er musikken ødelagt. Hver eneste node, hver eneste klang hører til helhedens struktur.

Måske også derfor blev han ikke rigtig accepteret af sin egen tid. Han var ikke så moderne som Schönberg, ikke så fuldstændig ny som Stravinsky med Sacre du 


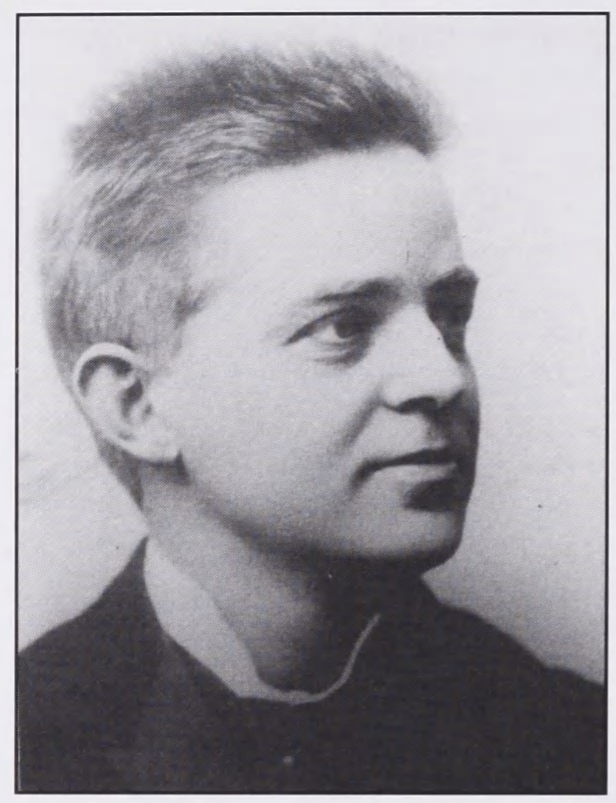

Komponisten Carl Nielsen (1865-1931) fotograferetca. 1905.

Printemps, han dyrkede videre på traditionen. Han var imidlertid heller ikke så sanselig som Strauss, ikke så ekshibitionistisk som Gustav Mahler, som alle er født omtrent samtidig. Nielsens musik er altid objektiv. Han har aldrig fremstillet sig selv og sine følelser, modsat Mahler, der i hver eneste node siger: JEG lider. Mahlers musik holder jeg også af, men jeg måtte lære at elske den, fordi denne form for selvfremstilling oprindelig var mig fremmed. Nielsen kunne og ville aldrig skrive som Mahler, det følte han som alt for egocentrisk. Mine, Carl Nielsens

Note

1. Herbert Blomstedt (f. 1927 i Sverige), efter flere topposter i det internationale musikliv Gewandhauskapellmeister i Leipzig 19982005; 1967-1977 chefdirigent for Radiosymfoniorkestret. følelser er ikke vigtige, de angår ikke verden. Men musikken, som jeg skriver, angår verden, fordi den tegner et billede af vores menneskelige situation. Nielsen var meget selvbevidst, men i hans musik er JEG ikke til debat, som den heller ikke er det i Sibelius'. Nielsen følte sig som en del af noget meget større end et JEG.

Et velegnet værk at begynde med og samtidig et højdepunkt i Nielsens produktion er den femte symfoni. Første sats skildrer konflikten mellem godt og ondt, kunne man sige, mellem orden og kaos, mellem det skønne og det dagligdags - det er alt sammen varianter af den samme grundide. Vel at mærke ser Nielsen her det dagligdags som det trivielle, som udgør en fare for vores liv. Allerede i 1922 så han forfladigelsen af livet som en fare. Det trivielle bliver symboliseret af en marchagtig figur i lilletrommen, en hverdagsagtig Figur, som imidlertid hele tiden breder sig mere og mere og derved bliver til en forbandelse og truer med at ødelægge hele musikken.

Denne sats er imidlertid også et godt eksempel på hvor intervalorienteret Nielsen tænkte. Centralintervallet er her tertsen. Man finder det straks ved begyndelsen i akkompagnementet. Efter få takter dukker tertsen også op som harmoni - fagotten bevæger sig næsten udelukkende i tertser. $\mathrm{Og}$ igen nogle få takter senere kommer tertsen så endelig som melodi. Nielsens musik er sammensat af helt enkle motiver - og dog utroligt udtryksfuld.

Skrevet til Partituren, Das Magazin fü klassische Musik, Nr. 1. Sommer 2005. - Oversat fra tysk af John Fellow. 